\title{
Chemical and nutritional changes in stored herring meal
}

4*. Nutritional significance of oxidation of the oil

\author{
BY K. J. CARPENTER \\ School of Agriculture, University of Cambridge \\ AND C. H. LEA AND L. J. PARR \\ Low Temperature Research Station, Cambridge \\ (Received 6 February 1962-Revised 4 October 1962)
}

This study was designed to investigate the nutritional significance of the interactions that may occur between oxidized fat and proteins in foods. Herring meal, because of its high content of protein and of highly unsaturated fat, was chosen as the material for study.

The first two papers in the series (Lea, Parr \& Carpenter, I958, 1960) dealt mainly with factors influencing the rate of oxidation of the fat in stored herring meal, and with the interaction between fat oxidation products and the $\epsilon$-amino groups of the lysine units in the herring protein. This paper describes feeding tests designed to discover whether the nutritional value of the protein was influenced in other ways also during storage, and to ascertain whether the oxidized and polymerized fat of the stored meal could itself be influencing the outcome of the feeding tests by direct toxic or 'growth-depressant' effect. The answer to the latter question appeared to be 'no'.

During this work an unexpected growth-depressant action was encountered with meal from which the oil had been extracted by chloroform-methanol, and these findings are reported. Included also is an account of a parallel study of a particular batch of imported anchovy meal said to have shown ' rancid fat toxicity' for livestock.

\section{EXPERIMENTAL}

\section{Materials}

Herring meal 4. A sample of herring meal was prepared from fresh herring in November 1959 at the same factory and in the manner already described for meal 3 (Lea et al. 1960), though only a little formaldehyde, used to harden the skin of the fresh herring, was added before processing. The meal was again packed immediately in solid $\mathrm{CO}_{2}$ for transport to the laboratory where it was gas-packed in oxygen-free nitrogen and stored at $-20^{\circ}$ until required. A sample of the expressed herring oil (I) produced at the same time in the first stage of pressing the herring was stored under $\mathrm{N}_{2}$ at $-20^{\circ}$.

Herring meal 5. This meal was prepared from Whitby herring during late August

* Paper no. 3, Brit. $¥$. Nutr. (1962), 16, 451. 
1959, at another factory but by a generally similar procedure. It had been stored commercially in a paper sack for to weeks before it reached the laboratory. The addition of antioxidants is now common commercial practice in fish-meal manufacture but none was added in the manufacture of herring meals $1-5$ used in this work.

Anchozy meal 6. A sample of anchovy meal, reputedly of Peruvian manufacture but otherwise of unknown history, was received in June 1960. It was despatched to us, through the courtesy of a commercial laboratory, as being part of a batch of material that had been suspected of causing feeding troubles in livestock and even of causing deaths in young pigs: it was suggested at the time that this toxicity might be attributable to the 'rancid' condition of the fat in such meals.

\section{Storage}

The meals (nos. 5 and 6) that had already been stored commercially before receipt were kept without special precautions in paper sacks at room temperature. After 2 months, however, no. 5 was gas-packed in $\mathrm{N}_{2}$ and stored at $-20^{\circ}$ to prevent further change.

Meal no. 4 was milled to a powder and divided into two portions. A portion for use as 'control' (4) was returned to storage at $-20^{\circ}$ in an atmosphere of $\mathrm{N}_{2}$. A second portion $\left.{ }_{4} \mathrm{~S}\right)$ was packed in cans with a large head space, periodically reflushed with air and stored at $20^{\circ}$ for I year; it was then returned to an atmosphere of $\mathrm{N}_{2}$ and held at $-20^{\circ}$ until required.

'Double-fat' meal. Fresh meal no. 4 contained $17.4 \%$ of lipid extractable with chloroform-methanol $(2: 1, \mathrm{v} / \mathrm{v})$ and soluble in chloroform. For preparation of a 'double-fat' meal, expressed herring oil (no. I), in solution in diethyl ether, was mixed with herring meal 4 in the ratio of $17.4 \mathrm{~g}$ oil to $100 \mathrm{~g}$ meal, and the solvent was evaporated. Part of this double-fat meal was then packed in $\mathrm{N}_{2}$ and held at $-20^{\circ}$ as a control $\left(D_{4}\right)$, and the remainder $\left(D_{4} S\right)$ was stored for a year in air at $20^{\circ}$ as described above before being returned to $-20^{\circ}$.

\section{Preparation of the solvent-extracted and recombined meals}

Extracted meal ${ }_{5} B$. This meal was prepared by extracting herring meal 5 with boiling chloroform-methanol $(9: \mathrm{I}, \mathrm{v} / \mathrm{v})$ for $2 \mathrm{~h}$ in a continuous-extraction apparatus, then filtering and removing the residual solvent from the meal by heating for $2 \mathrm{~h}$ at $50^{\circ}$ in a vacuum oven with a slow 'bleed' of $\mathrm{N}_{2}$.

Extracted meal ${ }_{5} \mathrm{C}$. It was prepared as was ${ }_{5} \mathrm{~B}$, but with two additional extractions of $30 \mathrm{~min}$ each with boiling diethyl ether, to ensure complete removal of the chloroform, before drying in the vacuum oven for $3 \mathrm{~h}$ at $60^{\circ}$.

Extracted meal ${ }_{5} D$. It was prepared as was ${ }_{5} \mathrm{C}$, but benzene-ethanol $(4: \mathrm{r}, \mathrm{v} / \mathrm{v})$ was used as initial extraction solvent in place of chloroform-methanol.

'Recombined' meals based on meals 5 and 6. For use in a feeding test (Expt 6, see p. r 55) designed to trace the cause of the poor growth on diets containing meal 6, the lipid from this meal was extracted and remixed with the fat-free solids from a 
normal meal (no. 5) to give recombined meal $\mathrm{S}_{5}$ L6. In the same way a recombined meal, S6L5, was prepared from the fat-free solids of meal 6 and the lipids of meal 5 . Each batch of fat-free solids was also recombined with its own lipid to give meals $\mathrm{S}_{5} \mathrm{~L}_{5}$ and S6L6, in order to detect any effect which might be introduced by the procedures of solvent extraction and evaporation. Although the proportions of lipid and fat-free solids in the original meals differed slightly, all remixing was done in the ratio of $x$ part of lipid to 7 parts of fat-free solids.

Meal 5 was extracted as described above in the preparation of $5 \mathrm{D}$, but the lipids of the anchovy meal (no.6) proved resistant to extraction with benzene-ethanol so chloroform-methanol had to be used as described above in the preparation of ${ }_{5} \mathrm{C}$. As with ${ }_{5} \mathrm{C}$, the extracted lipids were carefully freed from traces of residual solvent by the addition and subsequent removal under reduced pressure of diethyl ether, the process being repeated twice.

'Recombined' meals based on meals $D_{4}$ and $D_{4} S$. To distinguish possible direct adverse effects of the oxidized and polymerized lipid in the stored meals from effects of the non-fat fraction, recombined meals were prepared from $(a)$ the lipid of control $\left(-20^{\circ}, \mathrm{N}_{2}\right)$ double-fat meal $\mathrm{D}_{4}$ and the fat-free solids of the corresponding stored meal $\mathrm{D}_{4} \mathrm{~S}$ and $(b)$ the lipid of the stored meal and the fat-free solids of the control meal. Extraction (with chloroform-methanol) and remixing were carried out as described above, with the same precautions to ensure the complete removal of traces of residual solvent from both oil and fat-free residue.

Meal containing peroxidized oil. To test in a direct manner for any adverse effect in the diet of fish oil of comparatively high peroxide value, a sample of expressed herring oil (no. I) was exposed to the air in a thin layer at $25^{\circ}$ for 5 days, by which time it had attained a peroxide content of $142 \mu$ moles/g. This oil was then mixed with meal 4 in quantity equal to the amount of lipid already present $(17.4 \%)$, to produce a peroxidized double-fat meal $\mathrm{D}_{4} \mathrm{P}$.

It is worth recording that an attempt to develop a high peroxide value in lipid extracted from meal 4 by chloroform-methanol failed, the peroxide value after $\mathrm{I}_{4}$ days at $25^{\circ}$ being still $<4$, possibly because of an antioxidant or peroxide-decomposing action of the phospholipids present.

\section{Chemical examination}

Lipid content and properties. The analyses for lipid content of the meals and the characterization of the extracted lipids by iodine value and $\mathrm{N}$ content were carried out as previously described (Lea et al. 1958, 1960).

Solubility of the $N$. The method of measuring the solubility of the $\mathrm{N}$ of the meals after digestion with papain was that used by Olley \& Watson (196I), except that the $\mathrm{N}$ determinations were carried out on the residual insoluble material instead of on the filtrates.

'Available' lysine. For the determination of available lysine the procedure of Carpenter (1960), based on the reactivity of the free $\epsilon-\mathrm{NH}_{2}$ groups of lysine units in intact protein with fluorodinitrobenzene, was used. As with other materials of low carbohydrate content, it was assumed that $8 \%$ of the dinitrophenyllysine was lost in 
the acid-hydrolysis stage, and the values obtained were multiplied by 1.09 to compensate for this loss. This procedure has given results very similar to those from the procedure used previously (Lea et al, 1960) in which no blank deduction was usedthe blank deduction compensating closely for the loss on acid hydrolysis which also was not corrected for previously.

The determination of available lysine has hitherto usually been applied to samples without preliminary extraction of the fat, but in this series all the analyses have been replicated with fat-extracted samples. The results for the latter have been calculated on the basis of the $\mathrm{N}$ content of the original samples and the yield of material after fat extraction, no account being taken of the small proportion of the total $\mathrm{N}$ taken out by the solvent extraction.

\section{Microbiological assays}

Preparation of the samples. For microbiological assay the meals were first extracted with chloroform-methanol $(9: 1, v / v)$ and then with diethyl ether as described above for the preparation of sample ${ }_{5} \mathrm{C}$. The dry residues were then re-ground to pass a $\frac{1}{60}$ in. sieve.

Relative nutritive value (RNV). For measurement of the RNV each sample was supplied as the sole protein source to a vigorously proteolytic strain of Streptococcus zymogenes (Ford, 1960). The published procedure was followed except that the test materials were treated with a buffered solution containing twice the standard concentration of papain (non-crystalline grade; British Drug Houses Ltd, Poole) so that the final concentration of the enzyme preparation was $0.09 \%$. The growth response was measured turbidimetrically after incubation at $37^{\circ}$ for $48 \mathrm{~h}$, and expressed as a percentage of that produced by casein on an equal $\mathrm{N}$ basis.

Total and 'available' methionine. Similar procedures (Ford, 1962) were used for the determination of total and available methionine, $S$. zymogenes being supplied with a synthetic medium containing all the required amino acids except methionine, as well as the digest of the test protein. Values for methionine were then obtained by relating the growth response to that with pure L-methionine. For total methionine a digest prepared by autoclaving the test materials with $2 \mathrm{~N}-\mathrm{HCl}$ at $10 \mathrm{lb}$ pressure for $5 \mathrm{~h}$ was used. Two sets of values for available methionine were obtained, after pretreatment of the test materials with $0.09 \%$ or $0.36 \%$ of the papain preparation respectively, compared with $0.045 \%$ used in the original procedure. The small contribution of the enzyme itself to the final values was corrected for by subtracting values obtained in blank runs containing enzyme digests but no test material.

\section{Feeding tests}

Chick tests with semi-purified diets. The procedure in Expts I-4 was based on the conditions used by Laksesvela (1958) for the assay with chicks of protein quality in herring meals, though it must be noted that thiamine was omitted in error from the list of vitamin supplements given in that paper. In a preliminary experiment it was found that this omission led to the cessation of growth after only 6 days of the experimental treatments. Thiamine was included in subsequent experiments as shown below. 
Day-old cackerel chicks were purchased and reared for 6 days on a commercial diet containing an antibiotic supplement. At 6 days of age they were weighed, and those of very low or very high weight discarded; for this reason $50 \%$ more chicks were always obtained than were needed for the experimental treatments. Those retained were then divided into four strata by weight; from each stratum three chicks were allotted at random to each experimental treatment, and caged together as already explained (Lea et al. 1958). Thus twelve chicks, split up amongst four cages were allotted to each treatment. The experimental diets were then given $a d l i b$. for 8-12 days (as detailed in Table 3 ); the chicks were weighed on alternate days. Feed consumption was also measured in all but the first two experiments.

The experimental diets were all made from the same basal diet: ground oat husk ro, arachis oil $4.15, \mathrm{CaHPO}_{4} \cdot 2 \mathrm{H}_{2} \mathrm{O} 2, \mathrm{KCl} 0.5, \mathrm{NaCl} 0.3$, a trace-mineral mixture, a vitamin mixture and maize starch to 100 parts. The trace-mineral mixture was designed to contribute $\left(\mathrm{g} / \mathrm{100 \textrm {kg }}\right.$ diet): $\mathrm{MgSO}_{4} \cdot 7 \mathrm{H}_{2} \mathrm{O} 600$, ferrous citrate 160 , $\mathrm{MnSO}_{4} \cdot{ }_{4} \mathrm{H}_{2} \mathrm{O} 30, \mathrm{CuSO}_{4} \cdot{ }_{5} \mathrm{H}_{2} \mathrm{O} 20$, KI 6.5 and $\mathrm{ZnCO}_{3} 2 \cdot 7$; the vitamin mixture contributed ( $\mathrm{g} /$ roo kg diet) choline chloride ${ }_{5} 5^{\circ}$, Rovimix A and D (Roche Products Ltd, Welwyn Garden City; containing 8800 i.u. vitamin $A$ and 2200 i.u. vitamin $\mathrm{D}_{3} / \mathrm{g}$ ) 100, Rovimix E (Roche Products Ltd; containing 10 \% $\alpha$-tocopheryl acetate) 40 , inositol 6.5 , nicotinic acid 5 , calcium pantothenate $2 \cdot 7$, thiamine hydrochloride 0.8 , riboflavin 0.65 , pyridoxine hydrochloride 0.6 , menaphthone 0.26 , folic acid 0.16 and biotin 0.026 .

In each of the experiments the fish-meal preparations were included in the diets at a level calculated to contribute $12.5 \%$ crude protein $(\mathrm{N} \times 6.25)$; the level of arachis oil was reduced by the amount of lipid contributed by the fish meal, but the addition was otherwise entirely at the expense of maize starch. Meals $4,4 \mathrm{~S}, 5$ and 6 were therefore included at levels of $17 \cdot 8,17 \cdot 8,18 \cdot 5$ and $18 \cdot 7 \%$ respectively and contributed approximately $3 \cdot 2,3 \cdot 2,2 \cdot 5$ and $1 \cdot 6 \%$ chloroform-soluble lipid respectively. In Expt I two of the diets included $22 \%$ of soya-bean meal (contributing ro parts of crude protein) in addition to the fish meals; this further addition was made entirely at the expense of maize starch.

Immediately after preparation, each diet was transferred to small cans, sealed in $\mathrm{N}_{2}$ and stored at $0^{\circ}$. In this way the chicks could receive fresh food daily from a newly opened can. Food residues from the feed tins were discarded every $4^{8 \mathrm{~h}}$.

Chick tests with natural diets. Two further tests were done with diets containing fish-meal preparations used as supplements to ingredients of the kind usual in practical diets. In Expt 5, the two experimental diets each included $20 \%$ of fish meal and the other ingredients were $(\%)$ : ground wheat 25 , yellow maize meal 25 , wheat middlings 21.5, dehydrated grass meal 5 , dried brewer's yeast 3 and Drivite A and D (Boots Pure Drug Co. Ltd, Nottingham; containing 1000 i.u. vitamin A and 200 i.u. vitamin $\left.\mathrm{D}_{3} / \mathrm{g}\right) 0.5$. They contributed approximately a further $10 \%$ of crude protein to the diets.

In Expt 6, in which some reconstituted mixtures of 'fat-free solids' and lipids were used, the solids from meals 5 and 6 were included at the levels at which they were used in the previous experiment, 16.5 and $15.5 \%$ of diets $A$ and $B$ respectively. One 
part of lipid was added per seven parts of 'solids' for the reconstituted mixtures, as explained above. In diets $\mathrm{E}$ and $\mathrm{F} 20 \%$ of meal 6 was included, so contributing again $15.5 \%$ fat-free solids. The other ingredients in the diet were grass meal, yeast and Drivite all as in Expt 5, together with ground wheat 26.5 , wheat middlings 25 and yellow maize meal to 100 parts. For one treatment $0.015 \%$ of the antioxidant, 6-ethoxy-1,2-dihydro-2,2,4-trimethylquinoline (EMQ) was added to the diet, together with $0.085 \%$ arachis oil as a carrier; the other diets all included $0 . \mathrm{r} \%$ arachis oil and no antioxidant.

For Expts 5 and 6 the day-old cockerel chicks were weighed on arrival, and after removal of those of extreme weight the selected chicks were allotted, as in the previous experiments, to the different treatments and were now offered the experimental diets immediately, without any preliminary period on a commercial diet. The experiments continued for $18-20$ days.

Rat test. Five weanling albino males were taken from each of six litters. One rat from each litter was allotted to each of the five experimental treatments. The six rats allotted to each treatment were then caged in pairs, with the same arrangement for each treatment as regards litter origin of the pairs so as to simplify statistical analysis of the results. For a preliminary period of 3 days the same diet (no. 3 described below) was given to the rats in each cage; then the experimental diets were given for a further ro days and the live-weight gain and food consumption were recorded.

The ' $N$-free' diet no. I consisted of potato starch $\mathrm{x}_{5}$, maize oil (containing $0.15 \%$ EMQ, w/w) 13 , mineral mixture 4.22 , vitamins and sucrose (purchased as finely ground 'icing sugar') to 100 parts. The mineral mixture was prepared so as to contribute ( $\mathrm{g} / \mathrm{I} 00 \mathrm{~kg}$ diet): $\mathrm{NaH}_{2} \mathrm{PO}_{4}$ (anhydrous) I I $92, \mathrm{CaCO}_{3} 840, \mathrm{NaCl} 580$, $\mathrm{CaHPO}_{4} 544, \mathrm{KCl} 476, \mathrm{FePO}_{4} 240, \mathrm{~K}_{2} \mathrm{SO}_{4} 224, \mathrm{Mg}\left(\mathrm{CH}_{3} \mathrm{COO}\right)_{2} .4 \mathrm{H}_{2} \mathrm{O} 88, \mathrm{MnCl}_{2}$. ${ }_{4} \mathrm{H}_{2} \mathrm{O}_{3} 6, \mathrm{CuCO}_{3} \cdot 4, \mathrm{ZnCO}_{3} \mathrm{I} \cdot 2$ and $\mathrm{KI} 0_{4}$; vitamins were added to contribute ( $\mathrm{g} / \mathrm{I} 00 \mathrm{~kg}$ diet) choline chloride roo, Rovimix A and D 100 , Rovimix E 40, calci um pantothenate 4 , menaphthone 3 , nicotinic acid 2 , thiamine hydrochloride 0.6 , riboflavin 0.6 , pyridoxine hydrochloride 0.6 , folic acid 0.2 , biotin 0.015 and cyanocobalamin 0.002 . Diets 2 and 3 were prepared by adding 14.2 parts of meals 4 and $4 \mathrm{~S}$ respectively in place of 6.2 parts of sucrose, 5 parts of potato starch and 3 parts of maize oil in the mixture used for diet $I$. Finally diets 4 and 5 were prepared by mixing $99 \cdot 8$ parts of diets 2 or 3 respectively with 0.2 parts of L-cystine.

\section{RESULTS}

\section{Chemical and microbiological determinations}

The results obtained with the meals as received, and with meal 4 after further storage with and without added fat, are set out in Table $\mathrm{r}$. As with herring meal 3 (Lea et al. 1960), the amount of lipid extractable with diethyl ether was always considerably less than the chloroform-soluble fraction of the material extractable with chloroform-methanol.

Storage of meal 4 in air for a year resulted in a fall of 48 units in the iodine value of the extractable lipid. With the double-fat meal $\mathrm{D}_{4}$ the fall was only $2 \mathrm{I}$ units, so 
that even allowing for the double quantity of lipid, the absolute change in the number of iodine-reactive groups was slightly less. In contrast to the behaviour of meals I, 2 and 3 , which showed a fall of iodine value to well below roo after controlled storage with a large surface exposed to the air at 10, 20 or $25^{\circ}$ for 4 months (Lea et al. 1958, I960), meal 5 still had the comparatively high iodine value of 126 after the same period

Table $\mathrm{I}$. Results of the chemical analysis and microbiological assay for relative nutritive value and available methionine of meal 4 after various treatments and of meals 5 and 6

\begin{tabular}{|c|c|c|c|c|c|c|c|}
\hline & \multirow[b]{2}{*}{ Characteristic } & \multicolumn{6}{|c|}{ Meal no. } \\
\hline & & $\begin{array}{c}4 \\
\text { (fresh) }\end{array}$ & $\begin{array}{c}4 \mathrm{~S} \\
\text { (stored) }\end{array}$ & $\begin{array}{l}\mathrm{D}_{4} * \\
\text { (fresh; } \\
\text { double- } \\
\text { fat) }\end{array}$ & $\begin{array}{l}\mathrm{D}_{4} \mathrm{~S} \\
\text { (stored; } \\
\text { double- } \\
\text { fat) }\end{array}$ & $\begin{array}{c}5 \\
\text { (stored) }\end{array}$ & $\begin{array}{c}6 \\
\text { (stored) }\end{array}$ \\
\hline \multicolumn{8}{|c|}{ Composition } \\
\hline (i) & Moisture (\%) & $7 \cdot 6$ & - & $(6 \cdot 5)$ & - & 10.1 & $7 \cdot 9$ \\
\hline (ii) & $\mathrm{N} \times 6.25(\%)$ & $70 \cdot 6$ & - & $(6 o \cdot 1)$ & - & $67 \cdot 6$ & $66 \cdot 8$ \\
\hline (iii) & Ash (\%) & $9 \cdot 7$ & - & $(8 \cdot 3)$ & - & 13.8 & $16 \cdot 5$ \\
\hline (iv) & $\begin{array}{l}\text { Lipids extractable with diethyl } \\
\text { ether }(\%)\end{array}$ & 13.5 & - & $(26 \cdot 3)$ & - & $7 \cdot 0$ & $4 \cdot 2$ \\
\hline$(v)$ & $\begin{array}{l}\text { Lipids extractable with chloroform- } \\
\text { methanol }(2: 1, v / v)(\%)\end{array}$ & I $8 \cdot 4$ & - & $(30 \cdot 5)$ & - & 14.0 & II $\cdot 0$ \\
\hline (vi) & $\begin{array}{l}\text { Chloroform-soluble material present } \\
\text { in extract } \mathrm{v} \text { (as percentage of } \\
\text { original sample) }\end{array}$ & $17 \cdot 4$ & - & $(29 \cdot 6)$ & - & $13 \cdot 3$ & $8 \cdot 5$ \\
\hline (vii) & $N$ in extract vi $(\%)$ & - & $2 \cdot 2$ & 一 & $1 \cdot 0$ & $1 \cdot 4$ & $4 \cdot 2$ \\
\hline (viii) & Iodine value of extract vi & I 33 & 85 & $(132)$ & III & 126 & 88 \\
\hline \multicolumn{8}{|c|}{ Protein-quality tests $\uparrow$} \\
\hline (ix) & $\begin{array}{l}\mathrm{N} \text { solubility after pepsin digestion } \\
(\%)\end{array}$ & 97 & 95 & - & - & - & 89 \\
\hline$(\mathrm{x})$ & $\begin{array}{l}\text { Available lysine }(\mathrm{g} / \mathrm{1} 6 \mathrm{~g} \mathrm{~N}) \text { : } \\
\text { (a) no pretreatment } \\
\text { (b) after defatting }\end{array}$ & $\begin{array}{l}7 \cdot 87 \\
7 \cdot 93\end{array}$ & $\begin{array}{l}7 \cdot 53 \\
7 \cdot 36\end{array}$ & $\begin{array}{l}(7 \cdot 87) \\
(7 \cdot 93)\end{array}$ & $\begin{array}{l}7 \cdot 27 \\
7 \cdot 61\end{array}$ & $\begin{array}{l}7 \cdot 47 \\
7 \cdot 49\end{array}$ & $\begin{array}{l}5 \cdot 78 \\
5 \cdot 61\end{array}$ \\
\hline (xi) & 'Total methionine $(\mathrm{g} / \mathrm{1} 6 \mathrm{~g} \mathrm{~N})$ & $3 \cdot 35$ & $3 \cdot 22$ & $(3 \cdot 35)$ & $3 \cdot 34$ & $3 \cdot 33$ & $3 \cdot 11$ \\
\hline (xii) & $\begin{array}{l}\text { Available methionine }(\mathrm{g} / \mathrm{I} 6 \mathrm{~g} \mathrm{~N}) \\
\text { after digestion with: } \\
0.09 \% \text { papain } \\
0.36 \% \text { papain }\end{array}$ & $\begin{array}{l}2 \cdot 60 \\
3 \cdot 12\end{array}$ & $\begin{array}{l}2 \cdot 20 \\
2 \cdot 84\end{array}$ & $\begin{array}{l}(2 \cdot 60) \\
(3 \cdot 12)\end{array}$ & $\begin{array}{l}2 \cdot 25 \\
2 \cdot 97\end{array}$ & $\begin{array}{l}2 \cdot 21 \\
2 \cdot 99\end{array}$ & $\begin{array}{l}I \cdot 32 \\
2 \cdot 31\end{array}$ \\
\hline (xiii) & $\begin{array}{l}\text { RNV for } S . \text { zymogenes } \\
\quad(\text { casein }=100)\end{array}$ & 83 & 75 & $(83)$ & 73 & 70 & 56 \\
\hline
\end{tabular}

- Values calculated as those to be expected for a mixture of $100 \mathrm{~g}$ of meal 4 and $17.4 \mathrm{~g}$ of expressed herring oil I which was assumed to contribute only lipid, and was found to have an iodine value of $I 30$. $\dagger$ For tests $x(b)$, xi, xii and xiii, meal 6 was pre-extracted with chloroform-methanol $(2: 1, v / v)$ and the other meals with benzene-ethanol $(3: 1, v / v)$, before being twice washed with diethyl ether.

of storage under commercial conditions, but we do not know the initial value for this sample. The anchovy meal 6 of unknown age had an iodine value of 88 ; the iodine values of freshly expressed samples of anchovy oil have been reported as ranging from I 52 to 169 (Buttenberg \& Stüber, I906), values higher than those usually found for herring oil. 
The $\mathrm{N}$ content of the lipid extracted from meal $6(4 \cdot 2 \%)$ was also higher than the values of $2 \cdot 2$ and $1 \cdot 4 \%$ respectively for herring meals $4 \mathrm{~S}$ and 5 . Values of $4 \%$ or over were obtained by us only for a herring meal that had been heated at $130^{\circ}$ for $30 \mathrm{~h}$ (Lea et al. 1960).

It can be seen from Table 2 that, whereas chloroform-methanol $(9: \mathrm{I}, \mathrm{v} / \mathrm{v})$ was slightly more efficient than benzene-ethanol $(9: \mathrm{r}, \mathrm{v} / \mathrm{v})$ in the extraction of lipid from meal 5 and did not reduce the level of available lysine, it still gave a fat-free residue with an abnormally high chlorine content even after heating at $50^{\circ}$ for $2 \mathrm{~h}$ in a vacuum oven to remove solvent.

Table 2. Results of chemical analysis of untreated herring meal 5 and of the same meal extracted with chloroform-methanol $(9: 1, v / v)\left(5_{B} B\right)$ or with benzene-ethanol $(9: 1, v / v)$ $(5 D)$

Constituent
Moisture (\%)
Crude lipid extractable with chloroform-
methanol $(9: 1, \mathrm{v} / \mathrm{v})$ in $2 \mathrm{~h}(\%)$
Fat-free solids by difference $(\%)$
Available lysine (as percentage of
fat-free solids)
Chlorine (as percentage of fat-free
solids)

\begin{tabular}{ccc}
\multicolumn{3}{c}{} \\
$\overbrace{5}$ & $5 \mathrm{~B}$ & $5 \mathrm{D}$ \\
10.0 & 0.7 & 1.6 \\
13.7 & 0.0 & 1.3 \\
76.3 & 99.3 & 97.1 \\
6.62 & 6.64 & 6.53 \\
0.65 & 2.71 & -
\end{tabular}

Laboratory protein-quality tests. From Table $\mathrm{I}$ it can be seen that all the values for meal 4 were reduced by storage, the biggest percentage fall being that of from $\mathrm{I}_{4}$ to $16 \%$ in available methionine. The apparent drop in RNV was about $10 \%$, and the fall in available lysine was rather less. There was least change in ' $N$ solubility after pepsin'.

Meal 5 gave values of the same order as meal $4 \mathrm{~S}$, the corresponding herring meal stored at normal fat content but under experimental conditions. The anchovy meal 6 gave considerably lower values than these, the value for available methionine being approximately $60 \%$ of the corresponding values for meals $4 \mathrm{~S}$ and 5 , in contrast to the values for total methionine which showed little difference between the three meals, and little effect of storage.

The effect of defatting the meals before estimating their content of available lysine was small and not significant. On the other hand, increasing the level of papain in the pretreatment of the samples for the available methionine assay resulted in consistently higher values, the biggest proportional effect being with the poorest sample, no. 6 . However, the ranking of the samples was not changed by the alteration in the strength of the papain used for digestion.

\section{Feeding tests}

Chick tests with semi-purified diets. The results for the weight gains of the chicks in Expts I-4, with semi-purified diets, are summarized in Table 3, and the results of the statistical analyses for all the chick experiments are summarized in Table 5 .

In Expt I the chicks receiving meal 5 grew steadily, both with and without the further 
addition of soya-bean meal. Those receiving the chloroform-methanol extracted meal ${ }_{5} \mathrm{~B}$, on the other hand, grew very much more slowly, even in the first 2 days; plotting of successive weights showed a nearly even rate of gain. At the end of the main experimental period, six of the birds on diet $B$ were transferred to a similar diet with

Table 3. Daily weight gain, food consumption and food conversion efficiency of chicks in four experiments with semi-purified diets

\begin{tabular}{|c|c|c|c|c|c|}
\hline $\begin{array}{l}\text { Expt no.; } \\
\text { strain of chick; } \\
\text { age over trial }\end{array}$ & $\begin{array}{l}\text { Treat- } \\
\text { ment } \\
\text { code }\end{array}$ & Protein source in the diet & $\begin{array}{l}\text { Live-weight } \\
\text { gain } \\
(\mathrm{g} / \text { head })\end{array}$ & $\begin{array}{c}\text { Food } \\
\text { eaten } \\
\text { (g/head) }\end{array}$ & $\begin{array}{l}\text { Gain (g)/ } \\
\text { food eater } \\
\text { (g) }\end{array}$ \\
\hline \multirow{4}{*}{$\begin{array}{l}\text { I; } \\
\text { Rhode Island Red } \times \\
\text { Light Sussex; } \\
\text { 6-1 } 8 \text { days }\end{array}$} & A & Meal 5 & $8 \cdot 4$ & - & - \\
\hline & $\mathbf{B}$ & $\begin{array}{l}{ }^{\mathrm{B}} \text { (extracted } \\
\text { chloroform- } \\
\text { methanol) }\end{array}$ & $1 \cdot 4$ & - & - \\
\hline & $\mathrm{C}$ & $\begin{array}{l}5+\text { soya-bean } \\
\text { meal* }\end{array}$ & $12 \cdot 9$ & - & - \\
\hline & $\mathrm{D}$ & $\begin{array}{l}5 \mathrm{~B}+\text { soya-bean } \\
\text { meal }\end{array}$ & $3 \cdot 8$ & - & - \\
\hline \multirow{5}{*}{$\begin{array}{l}\text { White Leghorn } \times \\
\text { Rhode Island Red; } \\
6-14 \text { days }\end{array}$} & A & Meal 5 & $7 \cdot 6$ & - & - \\
\hline & B & $\begin{array}{l}\text { 5C (extracted } \\
\text { with chloroform- } \\
\text { methanol and } \\
\text { diethyl ether) }\end{array}$ & $6 \cdot 6$ & 一 & - \\
\hline & C & $\begin{array}{l}{ }_{5} \mathrm{C}+0.3 \% \mathrm{DL}- \\
\text { methionine }\end{array}$ & $6 \cdot 5$ & - & - \\
\hline & $\mathrm{D}$ & $\begin{array}{l}\text { 5D (extracted } \\
\text { with benzene- } \\
\text { ethanol and } \\
\text { diethyl ether }\end{array}$ & $7 \cdot 1$ & - & - \\
\hline & $\mathbf{E}$ & $\begin{array}{l}\text { Soya-bean meal }+ \\
\text { casein }\end{array}$ & $5 \cdot 5$ & - & - \\
\hline \multirow{5}{*}{$\begin{array}{l}3 \text { Brown Leghorn } \times \\
\text { Rhode Island Red; } \\
6-16 \text { days }\end{array}$} & A & Meal 4 (control) & $6 \cdot 8$ & $15^{\prime} \mathrm{I}$ & 0.45 \\
\hline & B & ${ }_{4} \mathrm{~S}$ (stored in air) & $5 \cdot 9$ & 13.5 & 0.44 \\
\hline & C & $\begin{array}{l}\mathrm{D}_{4} \mathrm{~S} \text { (double-fat, } \\
\text { stored in air) }\end{array}$ & $5 \cdot 1$ & $12 \cdot 6$ & 0.41 \\
\hline & $\mathbf{D}$ & 5 & $6 \cdot 4$ & $14^{\circ} \mathrm{I}$ & 0.46 \\
\hline & $\mathbf{E}$ & 6 (anchovy) & $3 \cdot 1$ & $10 \cdot 6$ & 0.30 \\
\hline \multirow{6}{*}{$\begin{array}{l}4 ; \\
\text { Brown Leghorn } \times \\
\text { Rhode Island Red; } \\
7-17 \text { days }\end{array}$} & A & $\begin{array}{c}\text { Meal } \mathrm{D}_{4} \text { (double-fat } \\
\text { control) }\end{array}$ & $7 \cdot 2$ & $15 \cdot 8$ & 0.46 \\
\hline & $\mathbf{B}$ & $\begin{array}{l}\mathrm{D}_{4} \text {, but diet } \\
\text { unprotected } \dagger\end{array}$ & $7 \cdot 4$ & I $5 \cdot 9$ & 0.47 \\
\hline & C & $\underset{\text { oil })}{\mathrm{D}_{4} \mathrm{P}}(+$ oxidized & $7 \cdot 5$ & $16 \cdot 1$ & 0.46 \\
\hline & $\mathrm{D}$ & Solids $\mathrm{D}_{4}+$ fat $\mathrm{D}_{4} \mathrm{~S}$ & $7 \cdot 6$ & $16 \cdot 3$ & 0.46 \\
\hline & $\mathbf{E}$ & $\begin{array}{c}\text { Meal } \mathrm{D}_{4} \mathrm{~S} \text { (double-fat } \\
\text { stored in air) }\end{array}$ & $5 \cdot 7$ & $14 \cdot 6$ & 0.39 \\
\hline & $\mathbf{F}$ & Solids $D_{4} S+$ fat $D_{4}$ & $6 \cdot 2$ & 14.5 & 0.43 \\
\hline
\end{tabular}

- The soya-bean meal contributed $10 \%$ crude protein in these two diets in addition to the standard $12.5 \%$ protein supplied by the fish-meal preparations in these, and all the diets used in Expts $1-4$.

+ This diet, after mixing, was stored with access to the air, whereas all the other diets were held under nitrogen until the day of use.

the benzene-ethanol extracted meal ${ }_{5} \mathrm{D}$, and in the following 8 days they had a daily live-weight gain of $6 \cdot 7 \mathrm{~g} / \mathrm{head}$, compared with a gain of only $\mathrm{I} \cdot \mathrm{I} \mathrm{g} / \mathrm{head}$ made by the six chicks remaining on the diet (B) containing the chloroform-methanol extracted meal ${ }_{5} \mathrm{~B}$. 
In Expt 2, meal 5 was compared from the beginning with both meal ${ }_{5} \mathrm{C}$, which had been prepared by extraction with chloroform-methanol followed by washing with diethyl ether, and meal $5 \mathrm{D}$ which had been prepared by benzene-ethanol extraction. The rates of weight gain of the chicks receiving ${ }_{5} \mathrm{C}$ and ${ }_{5} \mathrm{D}$ were respectively 88 and $94 \%$ of that of the chicks receiving the control meal 5 , the differences being without statistical significance. Further, chicks receiving ${ }_{5} \mathrm{C}$ with a supplement of methionine gained weight no faster than those given ${ }_{5} \mathrm{C}$ alone. All the chicks gained weight faster than those receiving their protein from a mixture of soya-bean meal and casein. Food consumption was not measured in these first two experiments.

It appears from these results that most of the growth-depressing property of the chloroform-methanol extracted meal $5 \mathrm{~B}$ was no longer present in meal $5 \mathrm{C}$ which had received two ether washes as well as a longer period in the vacuum oven.

For Expt 3 herring meal $4 \mathrm{~S}$, which had been stored for a year, was used. If the rate of live-weight gain of the chicks receiving the control meal 4 (stored in $\mathrm{N}_{2}$ at $-20^{\circ}$ ) is taken as 100 , the relative rates of gain on the same meal stored in air at $20^{\circ}(45)$ and of the double-fat meal stored in air $\left(\mathrm{D}_{4} \mathrm{~S}\right)$ were 87 and 75 respectively. The weight gain of the chicks was approximately proportional to the quantities of food eaten by them. It is possible therefore that the poorer gain in weight was the consequence of a lower acceptability of some diets. The efficiency of food conversion (i.e. $g$ gain in weight/g food eaten) was very similar on all three diets. The gain in weight of chicks on meal 5 , which had been stored in air for $4 \frac{1}{2}$ months, was intermediate between that of chicks receiving either the control meal 4 or the same meal stored for a full year in air $(4 \mathrm{~S})$. Both the rate of weight gain and the efficiency of food conversion of the birds receiving the anchovy meal 6 were poor.

In Expt 4, the stored double-fat meal $\left(\mathrm{D}_{4} \mathrm{~S}\right)$ was again included, this time with a fresh double-fat meal $\left(D_{4}\right)$ as control, and chicks receiving the former gained weight at a rate equivalent to $79 \%$ of the gain of those receiving the latter. However, the overall statistical analysis of the results of this experiment indicated a more than $5 \%$ probability of there being no difference between treatments, and comparison of individual treatments is not therefore strictly valid.

The treatments also included tests with mixtures of lipid extracted from one meal with residual solids from the other. Of the two mixtures, that containing the 'fresh' solids and 'stored' lipids supported the better weight gain in the chicks. Although differentiation of performance in individual diets is not valid, comparison of the mean gain of the chicks on the four treatments $A-D$ receiving the solids from meal $\mathrm{D}_{4}$ $(7.39 \mathrm{~g} /$ chick day) with that of the chicks on treatments $\mathrm{E}$ and $\mathrm{F}$ receiving the solids of meal $\mathrm{D}_{4} \mathrm{~S}\left(5^{\circ} .94 \mathrm{~g} /\right.$ chick day) showed a highly significant difference in favour of the former. The food consumption in groups A-D was also greater, so that the efficiency of food conversion was in the ratio of $100: 89$, whereas the ratio of weight gain for groups $\mathrm{A}-\mathrm{D}$ as compared with $\mathrm{E}$ and $\mathrm{F}$ was 100:80.

It can also be seen from the results of Expt 4 that, under the conditions used, the incorporation of herring oil oxidized so as to have a comparatively high peroxide value had no depressing effect on the chicks' rate of food consumption or on liveweight gain; nor had the storage of the mixed diet in air for a week before the experi- 
ment and during it any adverse effect. Indeed, the rate of weight gain with the solids of $\mathrm{D}_{4} \mathrm{~S}$ with partly oxidized fat (treatments $\mathrm{B}, \mathrm{C}$ and $\mathrm{D}$ ) was slightly, though not significantly faster than with treatment $\mathrm{A}$ in which the completely fresh material was used.

Table 4. Weight gain, food consumption and food conversion efficiency of chicks in two experiments with various fish-meal preparations given as supplements to other natural feeding-stuffs

\begin{tabular}{|c|c|c|c|c|c|}
\hline $\begin{array}{l}\text { Expt no.; } \\
\text { strain of chick; } \\
\text { age over trial }\end{array}$ & $\begin{array}{l}\text { Treat- } \\
\text { ment } \\
\text { code }\end{array}$ & Fish-meal preparation & $\begin{array}{c}\text { Daily } \\
\text { live-weight } \\
\text { gain } \\
\text { (g/head) }\end{array}$ & $\begin{array}{c}\text { Food } \\
\text { eaten } \\
\text { daily } \\
\text { (g/head) }\end{array}$ & $\begin{array}{l}\text { Gain }(\mathrm{g}) / \\
\text { food } \\
\text { eaten } \\
\text { (g) }\end{array}$ \\
\hline $\begin{array}{l}\text { 5; Light Sussex } \times \\
\text { Rhode Island Red; } \\
\text { O-20 days }\end{array}$ & $\begin{array}{l}\text { A } \\
\text { B }\end{array}$ & $\begin{array}{r}\text { Meal } 5 \\
6\end{array}$ & $\begin{array}{l}8 \cdot 7 \\
5 \cdot 0\end{array}$ & $\begin{array}{l}15.9 \\
11.2\end{array}$ & $\begin{array}{l}0.55 \\
0.45\end{array}$ \\
\hline $\begin{array}{l}\text { 6; Rhode Island Red } \\
\times \text { Light Sussex; } \\
\text { 0-18 days }\end{array}$ & $\begin{array}{l}\text { A } \\
\text { B } \\
\text { C } \\
\text { D } \\
\text { E } \\
\text { F }\end{array}$ & $\begin{array}{l}\text { Solids } 5+\text { fat } 5 \\
\text { Solids } 5+\text { fat } 6 \\
\text { Solids } 6+\text { fat } 5 \\
\text { Solids } 6+\text { fat } 6 \\
\text { Meal } 6 \\
\text { Meal } 6(+ \text { EMQ } \dagger)\end{array}$ & $\begin{array}{l}7 \cdot 8 \\
7 \cdot 3 \\
5 \cdot 2 \\
5 \cdot 1 \\
5 \cdot 6 * \\
5 \cdot 5 *\end{array}$ & $\begin{array}{l}14 \cdot 8 \\
14 \cdot 7 \\
11 \cdot 4 \\
12 \cdot 4 \\
12 \cdot 2 * \\
11 \cdot 2 *\end{array}$ & $\begin{array}{l}0.53 \\
0.49 \\
0.45 \\
0.41 \\
0.46 \\
0.49\end{array}$ \\
\hline
\end{tabular}

* As stated on p. 155, six of the twelve chicks used in each of these treatments received a vitamin supplement; values for them were included with those for the other chicks to give these mean values. $\uparrow$ 6-Ethoxy-1,2-dihydro-2,2,4-trimethylquinoline.

Table 5. Summary of the results of statistical analysis of the live-zveight gains in

$$
\text { Expts I-6 }
$$

\begin{tabular}{|c|c|c|c|}
\hline \multirow{2}{*}{$\begin{array}{l}\text { Expt } \\
\text { no. }\end{array}$} & \multirow{2}{*}{$\begin{array}{l}\text { Probability of } \\
\text { no overall } \\
\text { difference } \\
\text { between } \\
\text { treatments }\end{array}$} & \multicolumn{2}{|c|}{$\begin{array}{c}\text { Least significant differences }(P<5 \%) \\
\text { between mean gains }(\mathrm{g} / \mathrm{chick} \text { day) on } \\
\text { particular treatments }\end{array}$} \\
\hline & & Treatments compared & Value \\
\hline $\mathbf{I}$ & $<0.1 \%$ & $\begin{array}{l}A, C \text { and } D \\
B \text { and } A, C \text { or } D\end{array}$ & $\begin{array}{l}I \cdot 30 \\
I \cdot 44\end{array}$ \\
\hline 2 & $<\mathrm{I} \%$ & All & I.01 \\
\hline 3 & $<0.1 \%$ & All & 0.95 \\
\hline 4 & $>5 \%$ & All & $(1 \cdot 63) \dagger$ \\
\hline 5 & $<5 \%$ & (Only one comparison) & \\
\hline 6 & $<5 \%$ & $A, C$ and $D$ & $x \cdot 67$ \\
\hline & & $A, C$ or $\mathrm{D}$ and $\mathrm{B}$ or $\mathrm{F}$ & I.86 \\
\hline & & $A, C$ or $D$ and $E$ & $2 \cdot 16$ \\
\hline & & $B, E$ and $F$ & $2 \cdot 25$ \\
\hline
\end{tabular}

- Least significant differences with probabilities of $<\mathrm{I} \%$ and $<0.1 \%$ respectively of the differences being due to chance are approximately 1.45 and $2 \cdot 1$ times the corresponding values given in the table.

$\dagger$ Since the overall analysis showed no significant difference between treatments individual comparisons are invalid.

Chick tests with natural diets. The results of Expts 5 and 6 are summarized in Table 4. It will be seen that in Expt 5 the anchovy meal 6 again, with this different type of diet, gave a result very inferior to that obtained with herring meal 5 . Feed consumption was also lower with meal 6 , but not to the same extent, so that the ratio of weight gained to food eaten was also lower for meal 6 than for meal 5 . 


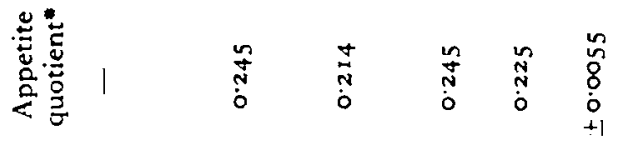

है

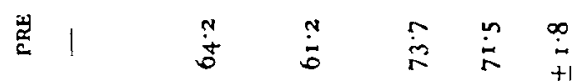

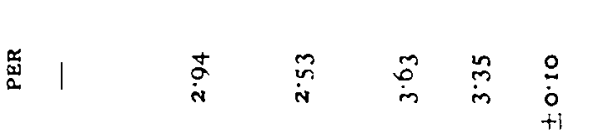

$\stackrel{\dot{m}}{2}$

这

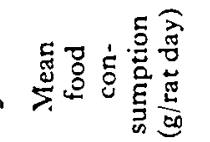

.ิ हิ

$\begin{array}{lllll}n & \alpha & \infty & 0 & y \\ 0 & 0 & 0 & 0 & 0\end{array}$

造

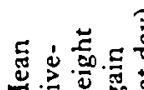

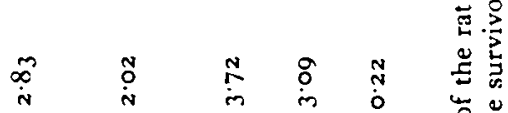

离劳

$\frac{2}{3} \frac{2}{\frac{2}{0}}$

$\left(\begin{array}{lll}0 \\ 0\end{array}\right\}$

$\begin{array}{llll}- & 0 & 0 & \infty \\ \dot{0} & \infty & \stackrel{4}{0} & \stackrel{2}{0}\end{array}$

垔

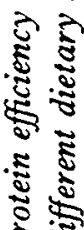

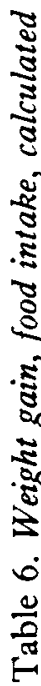

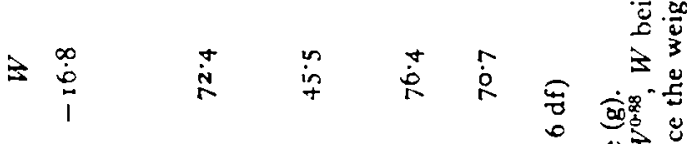

हैं

i்

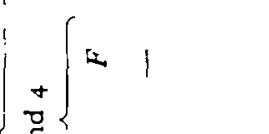

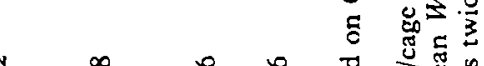

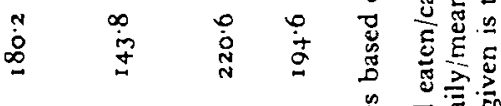

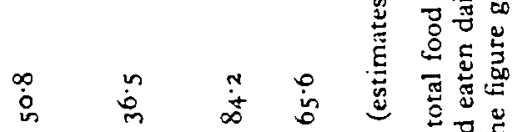

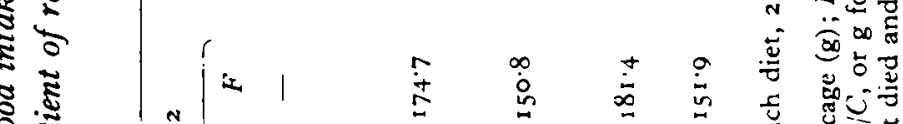

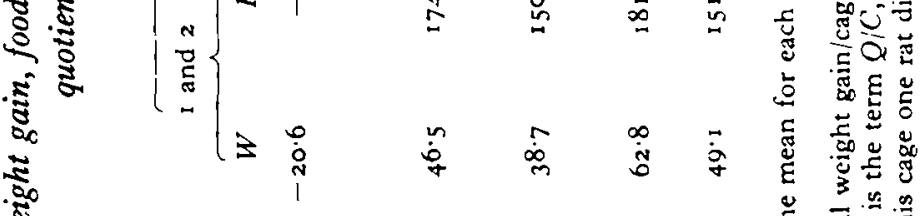

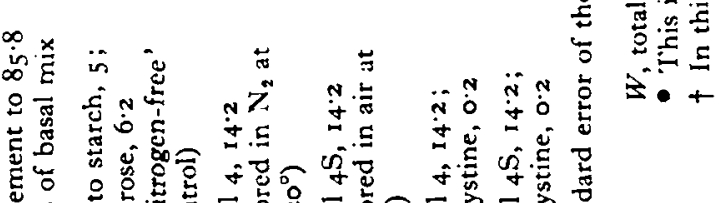

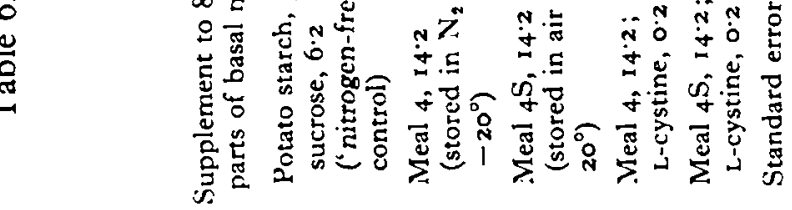

苟官一 - m 
For Expt 6, the fat-free solids and fat of meals 5 and 6 were separated and remixed in different ways. It can be seen from Table 4 that chicks receiving the solids from meal 5 gained weight faster than those receiving the solids from meal 6, regardless of the type of lipid with which the solids were mixed. It does not therefore appear to have been the extractable lipid fraction of meal 6 that was directly responsible for the slow gain in weight with this meal. Nor was the performance with meal 6 improved by addition of the antioxidant EMQ to the final mixed diet.

From the 8th day of the experiment one-half of the chicks receiving meal 6 , or meal $6+$ EMQ, had a vitamin supplement added to their diets, in the quantities used for the purified diets in Expts $\mathrm{I}-4$. Over the remainder of the experimental period the mean rate of gain of all the chicks given vitamin supplements was $7 \cdot 2 \mathrm{~g} / \mathrm{day}$, and that of the corresponding birds not given the supplements was $7.0 \mathrm{~g} /$ day: the small difference was not significant.

Rat test. A summary of the results is set out in Table 6. All the animals receiving the herring meals appeared to remain healthy, but one that received the ' $N$-free' diet died. The mean rate of weight gain of the rats receiving meal ${ }_{4} \mathrm{~S}$, that had been allowed to oxidize, was $7 \mathrm{I} \%$ of the value for those receiving the control meal 4 , but these rats also ate less so that the protein efficiency ratio (PER), calculated as g gain in weight/g protein eaten, was relatively less reduced-86\% that of those receiving meal 4. Another value, protein retention efficiency (PRE), takes into account not only the weight gain on the test diet, but also the sparing of the weight loss that occurred on the $\mathrm{N}$-free diet, and was calculated as $0.16 \times$ ( $\mathrm{g}$ gain in weight on test diet $+\mathrm{g}$ loss in weight on diet 1$) /(100 \mathrm{~g}$ protein eaten on test diet) (Bender $\&$ Doell, I957). The value of $P R E$ for the rats receiving meal ${ }_{4} \mathrm{~S}$ was $95 \%$ of that for the rats receiving meal 4 , the difference being without statistical significance.

The rats receiving the same two meals with a further supplement of $0.2 \%$ cystine showed a better performance by all three criteria. The relative performance with ' $4 \mathrm{~S}+$ cystine' was 83,92 and $97 \%$ of that with ' 4 + cystine' as judged by rate of weight gain, PER and PRE respectively.

Presumably the greater difference observed in weight gain than in the other measures is to be explained in terms of a lower appetite of the rats for the stored material. The 'appetite quotient' (Carpenter, 1953), a value derived in an attempt to measure such an effect, was in fact significantly lower for the two diets (with or without cystine) containing the oxidized meal than for the two diets containing the fresh meal. We cannot use this value to obtain figures in terms of metabolizable calories, but since the oxidized meal was probably slightly less well digested than the fresh meal, such conversion would only tend to widen the difference.

\section{DISCUSSION}

\section{Possible toxicity of the oxidized oil}

There has been considerable discussion in the past decade of the possible dangers associated with the presence of oxidized fats in both human and animal diets (cf. Colborn, I953; Greenberg \& Frazer, 1953; Kaunitz, 1960; Perkins, 1960) and analysts 
are sometimes expected to condemn or approve particular diets or ingredients on the basis of chemical analysis for such easily determined factors as peroxide value or even free fatty acids.

Several ways can be suggested in which autoxidation of the fat in foods might be harmful. The oxidized fat itself might be toxic through its content of peroxide or of polymerized or cyclized fatty acids, which it certainly is if included at very high levels in the diet. Fat oxidation may also impair appetite by its adverse effect on palatability. Finally, the nutritive value of fat-containing foods or diets can be reduced by protein damage such as we have been considering, or by the induction of particular vitamin deficiency states, either as a result of oxidative destruction or through increased vitamin requirements.

The experiments reported in this paper were all short-term ones using basal diets rich in all the known vitamins, and were not designed to provide evidence on possible effects on vitamins. However, the animals used, whether chicks or rats, were young and rapidly growing, so that any short-term toxicity effect or check to appetite should readily have become apparent. Moreover, the herring meal used in the tests was allowed to oxidize extensively so that the iodine value of its oil had fallen by nearly 50 units or, in one experiment, herring oil oxidized separately to a peroxide value of $142 \mu$ moles $/ g$ was added to it. The oxidized meals were given at twice the level that could be considered practical, and with the 'double-fat' meals this level meant a total addition of over $6 \%$ fat to the diet, or four times the practical level. These conditions can therefore be considered as extreme in relation to what might occur in practice, though they do not approach the severity of conditions adopted by some workers to demonstrate the toxic effects obtainable with oxidized fat. Diets containing as much as 10,15 or even $20 \%$ of strongly heated and oxidized fat have been given to laboratory animals, often causing depression of growth, or sometimes even loss of weight, and death. In a less extreme experiment $7 \%$ of fat oxidized to a peroxide value of $600 \mu \mathrm{moles} / \mathrm{g}$ and given to young rats depressed their rate of weight gain to about four-fifths of normal (Andrews, Griffith, Mead \& Stein, 1960).

The conclusion from our own experiments was that, although both the rats and the chicks gained weight more slowly on the oxidized meal $(4 \mathrm{~S})$ than on the control meal (4), the difference was not to be explained by any growth-depressant effect of the extractable lipid itself. If it had been so one would have expected that when the extractable lipid from the oxidized meal $\left({ }_{4} \mathrm{~S}\right)$ was mixed with the extracted solids of the fresh meal (4) the chicks would have performed less well with the mixture than with the entire fresh meal. In fact, in Expt 4 , in which the comparison was made, they did just as well. This finding is in agreement with other recent findings that the lipids extractable from stored herring meals did not depress the rate of weight gain of chicks (Laksesvela, 196I; March, Biely, Goudie, Claggett \& Tarr, I96I) and that solvent extraction of commercial herring meals had little or no effect on their value in chick diets (Biely, March \& Tarr, 1955; March, Biely \& Tarr, I957).

Kraybill \& Nilson (1947) also found no growth-depressant effect in rats over a 6-week period of a diet containing $3 \%$ of lipid extracted from a commercially stored sample of menhaden meal (the period of storage was not stated); but rats receiving 
a $15 \%$ supplement grew at only $75 \%$ the rate of controls receiving the same level of lard. Bender \& Haizelden (1957) could find no consistent effect of defatting a variety of fish meals on their biological values for rats.

Since it might be suspected that, under laboratory conditions, the particular set of circumstances needed for the development of fat toxicity had not been reproduced, we asked for the co-operation of field workers in obtaining a sample of fish meal (no. 6) that had been reported to show 'toxic rancidity' with farm animals. It was clear from Expts 3 and 5 that this meal was very much inferior nutritionally to meal 5 , but again it is apparent from Expt 6, in which the extractable lipids from meals 5 and 6 were interchanged, that this inferiority was associated with the residual solids rather than with the extractable lipid.

The results presented in this paper have therefore provided no evidence for the toxicity of oxidized fish lipids under the experimental conditions chosen. It must be repeated, however, that these conditions were not such as to bring out any vitamin deficiency effects; the need for precautions, such as the use of protected vitamin concentrates and of antioxidants to prevent the occurrence of vitamin $A$ or vitamin $E$ deficiency with diets rich in unsaturated fat, is already understood and non-controversial (cf. Singsen, Potter, Matterson, Bunnell, Kozeff \& Jungherr, 1955).

Laksesvela (1959) has shown that the level of free fatty acids in the lipid of herring meals is not a good indicator of their feeding value, and Branion, Dawson, Cavers \& Motzok (1938) had earlier come to the same conclusions for cod-liver oils. Our finding of normal results with a meal of artificially high peroxide value suggests that this criterion too is unlikely to be a useful indicator of the suitability of a sample of herring meal for feeding, probably because it is a measure only of a labile intermediate oxidation product.

\section{Feeding tests of protein quality in stored meals}

Our previous work (Lea et al. 1960) showed a fall of only $8-9 \%$ in the available lysine content of herring meals stored at $20-25^{\circ}$ for I year. This result, although supported by a biological assay, appeared to be somewhat in conflict with American reports indicating much greater declines in the proportional growth rates of chicks receiving as their sole sources of protein fish meals stored for varying periods (Grau, Kerrick, Lundholm \& Barnes, I959; Rand, Collins, Varner \& Mosser, 1960; L. E. Ousterhout \& D. G. Snyder, 1962, unpublished results).

We can now compare results obtained with fresh and stored meals in feeding tests of the same type with both chicks and rats. As was to be expected from the results of Miller (1956) and Njaa (1961), the sulphur-containing amino acids were the limiting factor in the rat test. Expressing the results for the 12 -month stored meal ${ }_{4} \mathrm{~S}$ (and in parentheses those for the double-fat stored meal $\mathrm{D}_{4} \mathrm{~S}$ also) as a percentage of the corresponding results with the control meal 4 , we have

$\begin{array}{lcc} & \begin{array}{c}\text { Chick } \\ \text { Expt } 3\end{array} & \begin{array}{c}\text { Rat } \\ \text { Expt }\end{array} \\ \text { Gain in weight } & 87(75) & 7 x \\ \text { Food intake } & 89(84) & 84 \\ \text { PER } & 98(90) & 86 \\ \text { PRE } & - & 95\end{array}$


If it is conceded that differences in growth rate, and even differences in PER, exaggerate apparent differences in protein quality when less is eaten of the inferior diet (Carpenter, 1953; Bender \& Doell, 1957) then a closer approach to a measure unaffected by appetite differences is that of PRE. This value is an indirect measure of net protein utilization (or $\mathrm{g} N$ retained/100 $\mathrm{g} N$ eaten) on the assumption that both the weight lost in the negative control group and that gained in the test groups contain $16 \%$ protein $(\mathrm{N} \times 6.25)$ (Bender \& Doell, 1957). PRE thus takes into account the diversion of some of the dietary protein for maintenance needs rather than growth. We cannot calculate PRE values for the chick experiments, but they would certainly be higher than the corresponding figures found for PER.

It would seem, therefore, that neither in the chick nor in the rat experiment was there a fall in protein quality during storage of more than 5-10\%, the larger differences in weight gain being explained by the additional factor of a drop of about $10 \%$ in the appetite of the experimental animals.

Whether or not this appetite-depressant effect exists, even to a smaller degree, when stored meals are included at a level of approximately $5 \%$ together with natural ingredients is not known for certain. It was not observed in two published experiments of this type comparing fresh and stored material (Evans, Carver \& Hamm, 1944; Lea et al. 1958).

\section{Laboratory tests of protein quality on stored meals}

Expressing the chemical values found for the stored meals (and in parentheses those for the double-fat stored meal $\mathrm{D}_{4} \mathrm{~S}$ also) as a percentage of those for the control meal 4 , as above, we have

$\begin{array}{ll}\text { Solubility of the } \mathrm{N} \text { after digestion with pepsin } & 98 \\ \text { Available lysine } & 94(94) \\ \text { Available methionine } & 88(9 \mathrm{I}) \\ \mathrm{RNV} & 90(88)\end{array}$

The figures quoted for available lysine and for available methionine are the means for each amino acid of the results obtained by the two variations of procedure described (pp. 153,154 ).

We know from other work (e.g. that of Dreosti \& Rowan, r959; Boyne, Carpenter \& Woodham, 196I) that ' $N$ solubility after pepsin' can very much underestimate nutritional damage. Moreover, the content of available methionine has been shown to fall proportionally more than that of available lysine during controlled heat treatment (Carpenter, Morgan, I,ea \& Parr, 1962) and the same has now been demonstrated as a result of storage. However, all the changes are small and of the same order as the experimental errors of the procedures, and we can only conclude that neither has given a grossly erroneous indication of the extent of the nutritional damage.

No certain explanation can at present be offered for the consistently lower nutritive value of the stored as compared with the control meals. It cannot be due to a physical barrier of oxidized and perhaps partly polymerized oil round the protein since the effect persists even after solvent extraction, and previous experiments have shown that chloroform-methanol is an efficient solvent for the lipids in oxidized herring 
meal (Lea et al. 1958). Nor can we hypothesize for methionine any binding mechanisms analogous to the reaction of lysine $\epsilon-\mathrm{NH}_{2}$ groups with aldehydes formed during the oxidation of fat. We have not shown directly that the fall in nutritive value of the material is a consequence of the oxidation of the fat, but circumstantial evidence that it is so is provided by our earlier observation that the fall in available lysine content did not occur $(a)$ in herring meal stored in $\mathrm{N}_{2}$ or $(b)$ in defatted herring meal stored in air. If the nutritive value of proteins per se deteriorated when the meals were in contact with the air one would expect to find evidence for it in the literature.

\section{The allegedly toxic meal}

Meal 6, the poorest sample in the series, was also the only anchovy meal. However, meal made from this fish can be of as high a quality as any other type of meal (Olley \& Watson, I $96 \mathrm{I}$; Carpenter \& Woodham, unpublished results). It is known that anchovy meal may overheat during storage, presumably as a consequence of the autoxidation of its highly unsaturated oil, with resultant damage to the quality of the protein. The observation that the level of total methionine in meal 6 was nearly equal to that for the other meals tested, whereas the level of available methionine was much lower, supports the suggestion that the low quality was due to subsequent heat damage rather than to any deficiency in the raw material. This suggestion is also in harmony with our failure to find any growth-depressing effect when the extracted lipid was given, and also with the low available lysine value of the meal and the high $\mathrm{N}$ content of the lipid-both of which have been produced experimentally in herring meal by deliberate heat damage (Lea et al. 1960 ).

In another small test (Carpenter, unpublished results), the same meal was given to a newly weaned piglet at increasing levels up to $15 \%$ of the diet without any harmful effect becoming obvious during the Io days' test. The meal was also assayed for histamine by a procedure using guinea-pig gut (Gaddum, 1935-6) and showed an apparent content of $0.01 \%$ : this is well below the lowest level of $0.12 \%$ found in meal made from spoiled tunny which caused depression of growth when given to chicks (Shifrine, Ousterhout, Grau \& Vaughn, 1959).

These observations combine to give the impression that, whereas meal 6 was undoubtedly of low protein quality, there was no evidence of its being directly toxic. It might be thought that perhaps the meal had gone through a toxic stage of oxidation. However, our experiment in which an oil meal specially prepared to have a considerable peroxide value was given to chicks failed to demonstrate any toxicity under the conditions used.

\section{Deleterious effect of extraction with chloroform}

Solvent extraction of meal 5 with chloroform-methanol $(9: \mathrm{I}, \mathrm{v} / \mathrm{v})$ followed by $2 \mathrm{~h}$ in a vacuum oven at $50^{\circ}$ to yield meal $5 \mathrm{~B}$ caused a severe fall in its nutritive value, as shown in Table 3 . The same solvent-extraction procedure, but followed by washing with ether before vacuum treatment, to give meal $5 \mathrm{D}$, had only a small and statistically insignificant effect (Expt 2). On analysis, meal 5 showed an increased chlorine content (Table 2), and it seems probable, therefore, that a small amount of chloroform 
was tenaciously held by the herring protein, and that this retained chloroform was responsible for reducing the performance of chicks on diets containing meals defatted by chloroform-methanol extract unless special precautions were taken to remove the solvent completely. Morrison, Sabry \& Middleton (1962) have recently made a similar observation with fish flours from which the bones had been separated by flotation in chloroform.

\section{SUMMARY}

I. Part of a sample of herring meal (no. 4) containing $17.4 \%$ lipids was held in nitrogen at $-20^{\circ}$ as control; another part (no. $4 \mathrm{~S}$ ) was stored in air at $20^{\circ}$ for 12 months during which the iodine value of its lipid fell from 133 to 85 . A 'double-fat' meal, prepared by blending expressed herring oil with the control meal, was similarly stored to give meals $\mathrm{D}_{4}$ and $\mathrm{D}_{4} \mathrm{~S}$ respectively.

2. Weanling rats receiving meal 4 as their sole source of protein (at a $10 \%$ level) gained $2.8 \mathrm{~g}$ /day; those receiving meal $4 \mathrm{~S}$ gained $2.0 \mathrm{~g} /$ day. With each diet there was a significant response to a supplement of cystine. The protein retention efficiencies (PRE) on the two diets were 64 and 60 respectively. The 'appetite quotient' of the rats receiving meal $4 \mathrm{~S}$ was $90 \%$ of that of those receiving meal 4 .

3. Chicks receiving meal 4 for 10 days as their sole source of protein (at a $12.5 \%$ level) gained $6.8 \mathrm{~g} /$ day; those receiving meals $4 \mathrm{~S}$ and $\mathrm{D}_{4} \mathrm{~S}$ gained 5.9 and $5 . \mathrm{I} /$ day respectively.

4. The lipids of meals $D_{4}$ and $D_{4} S$ were extracted and re-mixed, each with the fat-free solids of the other. When these mixtures were given to chicks, growth depression was observed with the diets containing the non-fat solids from the air-stored meals $\left(\mathrm{D}_{4} \mathrm{~S}\right)$, but not with those containing the oxidized lipids. The addition to the diet of $2.5 \%$ herring oil pre-oxidized to a peroxide value of $\mathrm{I}_{42} 2 \mu \mathrm{moles} / \mathrm{g}$ also failed to depress growth.

5. In laboratory tests meal 4 showed $97 \%$ nitrogen solubility after pepsin digestion, $7.9 \mathrm{~g} / 16 \mathrm{~g} \mathrm{~N}$ of available lysine (fluorodinitrobenzene method), $2.9 \mathrm{~g} / 16 \mathrm{~g} \mathrm{~N}$ of available methionine (mean of results by two procedures with Streptococcus zymogenes) and a relative nutritive value (RNv) of 83 . The corresponding figures for meal $4 \mathrm{~S}$ were respectively $98,94,88$ and $90 \%$ of these values. The figures for meal $\mathrm{D}_{4} \mathrm{~S}$ did not differ significantly from those for meal $4 \mathrm{~S}$.

6. An allegedly toxic sample of anchovy meal (no. 6) supported a growth rate of only $3 . \mathrm{I}$ /day in chicks, but the extractable lipids were again found not to be growthdepressant. The meal gave low values in the laboratory protein-quality tests and may well have become overheated (scorched) during storage as a result of lipid oxidation.

7. In a preliminary experiment a herring meal (no. 5) extracted with chloroformmethanol to remove the lipid and then heated in a vacuum oven to remove the solvent, supported only poor growth. Since further washing of the extracted meal with diethyl ether largely restored its value for chicks it was concluded that the effect was probably due to the toxicity of firmly held residual chloroform. 
We thank Mr E. L. Miller, Dr C. B. Morgan and Miss V. Evans for carrying out the rat-feeding experiment, the microbiological assays and statistical analyses respectively.

\section{REFERENCES}

Andrews, J. S., Griffith, W. H., Mead, J. F. \& Stein, R. A. (1960). 7. Nutr. 70, 199.

Bender, A. E. \& Doell, B. H. (1957). Brit. Y. Nutr. II, I40.

Bender, A. E. \& Haizelden, S. (1957). Brit. F. Nutr. Ix $_{2} 42$.

Biely, J., March, B. E. \& Tarr, H. L. A. (1955). Poult. Sci. 34, 1274.

Boyne, A. W., Carpenter, K. J. \& Woodham, A. A. (1961). F. Sci. Fd Agric. 12, 832.

Branion, H. D., Dawson, A. F., Cavers, J. R. \& Motzok, I. (1938). Poult. Sci. 17, 213.

Buttenberg, P. \& Stüber, W. (1906). Z. Nährungsmittel, 12, 34 I.

Carpenter, K. J. (1953). F. Nutr. 5I, 435.

Carpenter, K. J. (1960). Biochem. Э. 77, 604.

Carpenter, K. J., Morgan, C. B., Lea, C. H. \& Parr, L. J. (1962). Brit. Y. Nutr. 16, 45 r.

Colborn, L. R. (1953). Vet. Rec. 65, 579.

Dreosti, G. M. \& Rowan, A. N. (1959). Fishing Industry Research Institute (Cape Town), x 2th Annu. Rep. p. 42.

Evans, R. J., Carver, J. S. \& Hamm, W. S. (1944). Poult. Sci. 23, 491.

Ford, J. E. (1960). Brit. Y. Nutr. 14, 485 .

Ford, J. E. (1962). Brit. F. Nutr. 16, 409.

Gaddum, J. H. (1935-6). Proc. R. Soc. Med. 29, 1373.

Grau, C. R., Kerrick, N. L., Lundholm, B. D. \& Barnes, R. N. (1959). Comm. Fish. Rev. $21,7$.

Greenberg, S. M. \& Frazer, A. C. (1953). F. Nutr. 50, 421.

Kaunitz, H. (1960). Exp. Med. Surg. 18, 59.

Kraybill, H. F. \& Nilson, W. H. (1947). Comm. Fish. Rev. p. 7, October 1947.

Laksesvela, B. (1958). F. agric. Sci. 5I, 164.

Laksesvela, B. (1959). Arch. Gefligelk. 23, 88.

Laksesvela, B. (1961). Meldinger SSF, January 1961, p. 7. Quoted in Nutr. Abstr. Rev. (1961), 31, 1434 .

Lea, C. H., Parr, L. J. \& Carpenter, K. J. (1958). Brit. F. Nutr. 12, 297.

Lea, C. H., Parr, L. J. \& Carpenter, K. J. (1960). Brit. Y. Nutr. 14, 91.

March, B. E., Biely, J., Goudie, C., Claggett, F. \& Tarr, H. L. A. (196r). F. Amer. Oil Chem. Soc. 38, 80.

March, B. E., Biely, J. \& Tarr, H. L. A. (1957). Progr. Rep. Pacif. Coast Stas Nanaimo \& Vancouver, no. 108, p. 24.

Miller, D. S. (1956). 7. Sci. Fd Agric. 7. 337.

Morrison, A. B., Sabry, Z. I. \& Middleton, E. J. (1962). F. Nutr. 77, 97.

Njaa, L. R. (196r). F. Sci. Fd Agric. 12, 757.

Olley, J. \& Watson, H. (1961). F. Sci. Fd Agric. 12, 316.

Perkins, E. G. (1960). Food Tech. 14, 508.

Rand, N. T., Collins, V. K., Varner, D. S. \& Mosser, J. D. (rg6o). Poult. Sci. 39, 45.

Shifrine, M., Ousterhout, L. E., Grau, C. R. \& Vaughn, R. H. (r959). Appl. Microbiol. 7, 45.

Singsen, E. P., Potter, L. M., Matterson, I. D., Bunnell, R. H., Kozeff, A. \& Jungherr, E. L. (1955). Poult. Sci. 34, 1075 . 